\title{
Pests and diseases on Falcataria moluccana trees in agroforestry systems with pineapple in East Java, Indonesia
}

\author{
SRI RAHAYU`, ANANTO TRIYOGO, SITI M. WIDYASTUTI, MUSYAFA', FIQRY ARDIANYAH \\ Department of Silviculture, Faculty of Forestry, Universitas Gadjah Mada. Jl. Agro No. 1, Bulaksumur, Sleman 55281, Yogyakatra, Indonesia, \\ Tel.: +62-274-550541, vemail: sri.rahayu2013@ugm.ac.id
}

Manuscript received: 21 January 2021. Revision accepted: 23 April 2021.

\begin{abstract}
Rahayu S, Triyogo A, Widyastuti SM, Musyafa', Ardianyah F. 2021. Pests and diseases on Falcataria moluccana trees in agroforestry systems with pineapple in East Java, Indonesia. Biodiversitas 22: 2779-2788. The agroforestry system using Falcataria moluccana (Sengon) and Ananas comosus (pineapple) is considered as a profitable intercropping system in Indonesia. To make it viable, it is necessary to evaluate the effect of mixed cropping on the incidence and severity of diseases and pests on Sengon trees and apply management measures. The present study was conducted (i) to assess the pest and disease problems on Sengon trees in the agroforestry system and (ii) to identify the most harmful pathogen/pest which affects the growth and causes mortality of Sengon trees at the beginning of intercropping and after the removal of pineapple from the system. Incidence of pests and diseases were assessed in 3 replicate blocks with one-year-old Sengon trees mixed with pineapple, and in another 3 plots with four-year-old Sengon trees from where pineapple was removed after harvesting. Sengon and pineapple were planted in the plots using alley cropping method with $3 \mathrm{x}^{\mathrm{m}} \mathrm{m}^{2} \mathrm{spacing}$. The results showed that there were no significant pest and disease problems on pineapple. However, Sengon was infested by the white grub Lepidiota stigma, gall rust caused by the fungus Uromycladium falcatarium, the stem borer Xystrocera festiva, and mistletoe Scurrula sp. However, stem borer and gall rust were the only pest and disease issues recorded in the monocultures of Sengon in Indonesia. The occurrence of stem borer and gall rust disease had a significant effect on the diameter growth of trees and in some instances, these caused mortality of one-year-old trees. Significant mortality of fouryear-old trees was caused by mistletoe infestation only. Although the incidence of gall rust and stem borer in the agroforestry system was not significantly low compared to the monoculture, the former had wider spacing between trees, more open canopy and resultant low humidity and faster wind speed reduced the severity of the gall rust disease and stem borer attack. However, the intercropping resulted in the white grub attack on young Sengon trees which calls for application of contaminant-free fertilizers in pineapple plantings.
\end{abstract}

Keywords: Agroforestry, Ananas comosus, Falcataria moluccana, gall rust disease, mistletoe, stem borer

\section{INTRODUCTION}

One of the main purposes of agroforestry system is nullification of the harmful effects of monoculture which is more susceptible to pests and diseases. However, the effect of intercropping in agroforestry systems on the incidence of pests and diseases on different crops is poorly known in Southeast Asia. According to Saikia et al. (2017), agroforestry refers to a land-use system in which trees are grown in association with agricultural crops, pastures, or livestock, whereby there occur ecological and economic interactions between the components. Schroth et al. (2000) stated that harnessing diversity by planting different species together is one of the simplest strategies to reduce the risk of pests and diseases. Some species in this combination will continue to survive and grow better when others are often damaged by pest and disease outbreaks. However, there are examples where both the species benefit. Therefore, agroforestry is a useful practice in both economic and ecological aspects.
In agroforestry systems in Java, Falcataria moluccana (Miq.) Barneby \& Grimes) (Sengon) and pineapple (Ananas comosus (L) Merr) are widely grown in agroforestry systems. Sengon is a fast-growing, easily cultivated, nitrogen-fixing, and economically valuable tree species (Krisnawati et al. 2011; Kosuke et al. 2013) grown under plantations in the country. Pineapple is a tropical shrub that is easy to cultivate and offers great economic value and market opportunity for its fruits. Sengon is usually harvested at the age of 5-6 years, while fruits of pineapple are harvested at 12 to 24 months. Sengon gives pineapple a shadow effect which lowers sunburn in pineapples and promotes better productivity and adds to the quality of the fruit (Weifeng et al. 2020). On the other hand, Sengon benefits from the intensive maintenance of pineapple. In general, the agroforestry systems also reduced the cost of maintenance compared to the monoculture plantation. However, there were no studies on the influence of Sengon-pineapple agroforestry system on the occurrence of pests and diseases on Sengon trees at 
Perum Perhutani (Indonesian State-owned Forestry Enterprise) in Kediri, East Java.

Pineapple plants are usually removed from the system in 2-3 yrs after the rotation which turns the ecosystem back to a monoculture. As a result, the disease and pest issues that occurred on Sengon trees in their early stages of growth continued to develop which posed threat to the health of the trees. According to Palma et al (2019), the effect of adding a new species to an agroforestry system on the pest and disease situation often depends on the characteristics of the species rather than on the increase of species diversity. When unsuitable species are added, agroforestry systems are likely to experience equal or even higher incidence of pests and diseases compared to simpler cropping systems. Most of the previous research on the agroforestry system and disease-causing organisms focused more on combination involving agricultural species (Wijayanto, 2011).

Against this background, the current work was aimed to 1) assess the pest and disease problems on Sengon trees in the agroforestry system and 2) identify the most harmful pathogen/pest which affects the growth and causes mortality of Sengon trees at the beginning of intercropping and after the removal of pineapple from the system.

\section{MATERIALS AND METHODS}

\section{Study area}

This research was conducted at RPH Pandantoyo, BKPH Pare, KPH Kediri, a forest management unit of Perum Perhutani in East Java, Indonesia (Figure.1). KPH Kediri is the largest forest management unit in Perum Perhutani, which specializes in growing Sengon trees using agroforestry system, mostly with pineapple. Pineapple was planted and managed by the members of the local community who hold the land under lease for at least 2 years. Pineapple is usually planted between Sengon trees, for at least 2 years, after which the plant was removed. The growers will then move to another block where the Sengon trees are still young $(<1 \mathrm{yr}$-old) and plant pineapple. The survey and data collection were carried out from 3 blocks of one-year-old Sengon trees under agroforestry system with pineapple, and another 3 blocks of four-year-old trees already freed from the pineapple crop. F. moluccana and pineapple were planted using alley cropping method with a spacing of $3 \times 4 \mathrm{~m}^{2}$ among the trees, and $40 \times 60 \mathrm{~cm}$ spacing between pineapple.

\section{Methods}

Assessment of pests and diseases on Sengon trees

A preliminary survey showed that pineapple is free from any significant pest and diseases. However, several pests and pathogens were recorded on Sengon trees, e.g., drying and death of young trees under the age of 5 months caused by white grubs, stem borer attack, gall rust disease and infestation by mistletoe. To assess the incidence and severity of pests and diseases, ten plots of $20 \mathrm{~m} \times 20 \mathrm{~m}$ each were established in three blocks. The number of trees in a single plot was about 30 .

Incidence of white grub $(\mathrm{WGI})=(\mathrm{n} / \mathrm{N}) \times 100 \%$

Where:

$\mathrm{n}$ : number of trees died due to white grubs

$\mathrm{N}$ : number of total trees in the plot

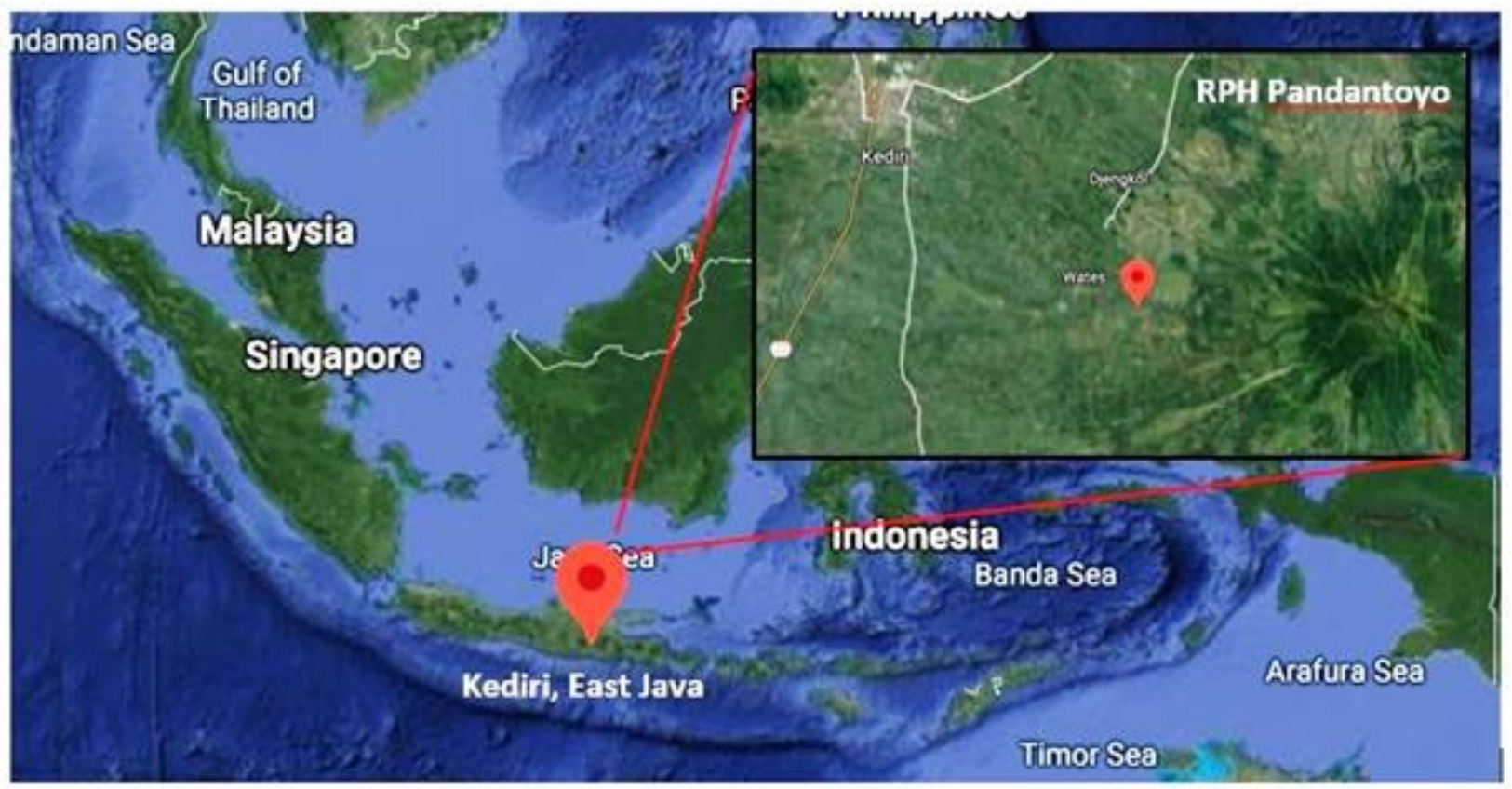

Figure 1. The location of RPH Pandantoyo, Kediri, East Java, Indonesia (-790'62.17’'S, 112¹9'98.816”W) 
The stem borer was assessed by calculating the length of the stem damaged by stem borer on the upper and lower stem. The formula used was a modification from Endang and Farikhah (2010) as follows:

Stem borer incidence $(\mathrm{SBI})=(\mathrm{n} / \mathrm{N}) \times 100 \%$

Stem borer severity (SBS), at the lower stem (SBSLS); upper stem $($ SBSUS $)=(1 / L) \times 100 \%$

Where:

SBI : stem borer incidence

SBS : stem borer severity

LS : lower stem

US : upper stem

$\mathrm{n} \quad$ : number of trees with stem borer in each position on trees

$1 \quad$ : length of stem damage by stem borer

$\mathrm{L} \quad$ : height of the trees

$\mathrm{N}$ : Total number of trees in one plot

The severity of the gall rust disease was assessed considering the number of galls on each tree on the lower stem (LS) (from the base of the tree to the height at breast level) and upper stem (US) (starting from breast height level until the bole, branches, and crown, including leaves and twigs). The formula for gall rust disease incidence and severity were modified from Rahayu et al. (2018) as follows:

Gall rust disease incidence $(\mathrm{GRDI})=(\mathrm{n} / \mathrm{N}) \times 100 \%$

Gall rust disease severity (GRDS), at the lower stem (GRDSLS); upper stem (GRDSUS), branch (GRDSB0) and canopy $($ GRDSC $),=(\mathrm{g} / \mathrm{G}) \times 100 \%$

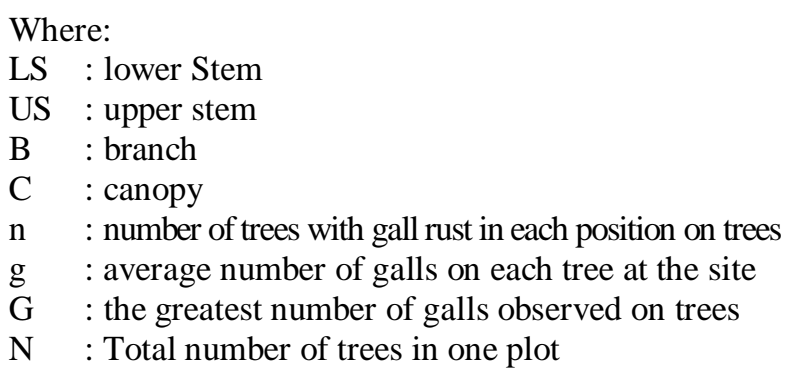

The total incidence and severity of gall rust disease and stem borer were the total incidence or severity in each part divided by number of parts observed.

Mistletoe (M) incidence and severity were calculated using formula:

Mistletoe incidence $(\mathrm{MI})=(\mathrm{n} / \mathrm{N}) \times 100 \%$

Mistletoe severity $(\mathrm{MS})=(\mathrm{m} / \mathrm{M}) \times 100 \%$

Where:

MI : mistletoe incidence

MS : mistletoe severity

$\mathrm{m} \quad$ : number of mistletoes in each tree
M : highest numbers of mistletoes observed during this study

$\mathrm{n} \quad$ : number of trees with mistletoes

$\mathrm{N}$ : Total number of trees in one plot

To estimate the growth of trees, diameter at the breast height of each tree was measured and computed. The overall percentage of death of one-year-old and four-yearold trees due to pests and diseases was also assessed using the formula:

Percentage death of trees $(\mathrm{DT})=(\mathrm{n} / \mathrm{N}) \times 100 \%$

Where:

$\mathrm{n} \quad$ : number of dead trees in a plot

$\mathrm{N}$ : number of total trees in the plot

The status of each pest and disease problem and mistletoe attack was categorized as follows (Sharma et al. 2010).

\section{Analyses of data}

Analysis of variance was used to compare incidence and severity of gall rust disease, stem borer and mistletoe incidence in each block and significance of differences in tree height and percentage of death of trees. Step-wise multiple linear regression analysis was used to determine which variables are significantly related to diameter of the trees and percentage death of Sengon trees. All analyses were performed using statistical package of $\mathrm{R}$ (ver.3.6.1).

\section{RESULTS AND DISCUSSION}

\section{Results}

Several pests, diseases, and plant parasites infested Sengon trees within the agroforestry system with pineapple. Also, the infestations continued even after the intercropping was discontinued. The major pests and diseases on the trees were: gall rust caused by the rust fungus Uromycladium falcatarium, stem borer caused by Xystrocera festiva, and death of young trees caused by the white grub viz., Lepidiota stigma, and infestation by the mistletoe Scurrula sp.

The grub L. stigma caused significant damage on threemonth-old Sengon plants in the intercropped agroforestry systems at Pandantoyo, Kediri. The grub caused damage to more than $5 \%$ of roots which lead to the death of young trees. Consequently, transplanting had to be carried out and insecticides such as Carbofuran had to be applied to protect the trees in the field. However, the distribution of the white grub was limited to certain locations. So, for the purposes of this study, blocks which were free from white grub attack was selected for data collection and information on the incidence of white grub was not included in the analyses (Table 1). 
Table 1. Status of gall-rust disease, stem borer and mistletoe incidence (DI), and severity (DS) on trees

\begin{tabular}{llll}
\hline DI & Incidence status & DS & Severity status \\
\hline$<10 \%$ & Rare & $0 \%$ & Nil \\
$10-<25 \%$ & Occasional & $<25 \%$ & Low \\
$25-<50 \%$ & Common & $25-<50 \%$ & Medium \\
$50-<75 \%$ & Very common & $50-<75 \%$ & Severe \\
$>75 \%$ & Widespread & $75-100 \%$ & Very severe \\
\hline
\end{tabular}

The stem borer viz., Xystrocera festiva is one of the most damaging insects that infest many tree species belonging to the family Fabaceae including Sengon trees which is native to western Indonesia (Java, Sumatra, and Kalimantan). The total incidence of stem borer (TOTISB) on one-year-old trees was lower than that on four-year-old trees. However, the severity of stem borer (TOTSBS) on one-year-old trees was higher than that on four-year-old trees. The severity of stem borer on the upper stem, both on one-year-old and four-year-old trees contributed largely to the total severity of stem borer on the trees (Figure 3). Although there are reports that infestation of stem borer on Sengon trees usually begins when the tree is three-year-old, under the agroforestry system with pineapple, the infestation was found severe on one-year-old trees in this study.

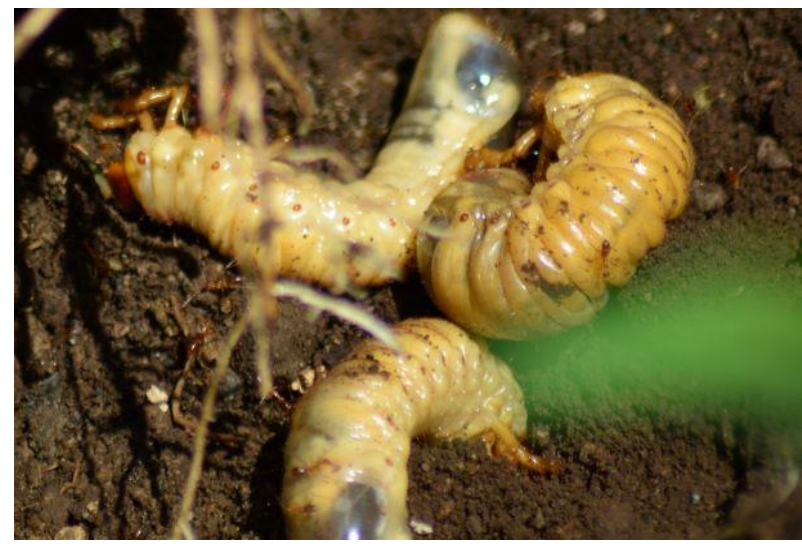

A

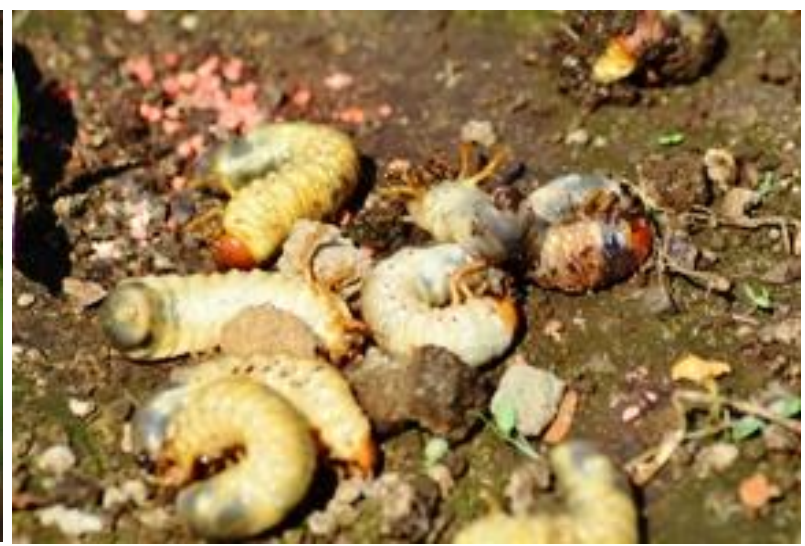

B
The gall rust disease started to develop on Sengon trees when the trees were three-month-old. The most severe symptoms on young trees were formed on the leaf and branch (Figure 4.A). The fungus produced reddish-brown teliospores on the branches within a short period (Figure 4.B).

The gall rust incidence (TOTGRDI) on one- and fouryear-old trees was $50 \%$ and $80 \%$, respectively. However, the disease severity (TOTGRDS) on these trees (about $0.56 \%$ and $3 \%$ in one-year-old and four-year-old trees, respectively) was exceptionally low (Figure 5). The gall rust disease severity on different tree parts was generally low, with the branch (GRDSB) and canopy (GRDSC) being comparatively more affected on one-year-old trees (about 1.3\%), and the upper stem (GRDSUS) in four-yearold trees $(4 \%)$ than other parts (Figure 6). The high incidence of the disease in the study plots indicates that the rust fungus could easily spread within the study area. Although the disease severity was low, the pathogen being an obligate parasite was able to persist throughout the lifecycle of Sengon trees. It is evident that the incidence and severity of the gall rust were significantly low in oneyear-old trees intercropped with pineapple compared to four-year-old where the pineapple cultivation has been abandoned after harvest.

Figure 1. A. The white grub Lepidiota stigma attacking the root of young Sengon trees, B. dying white grab after the application of insecticide in the agroforestry system

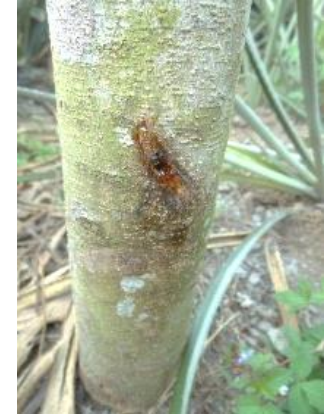

A

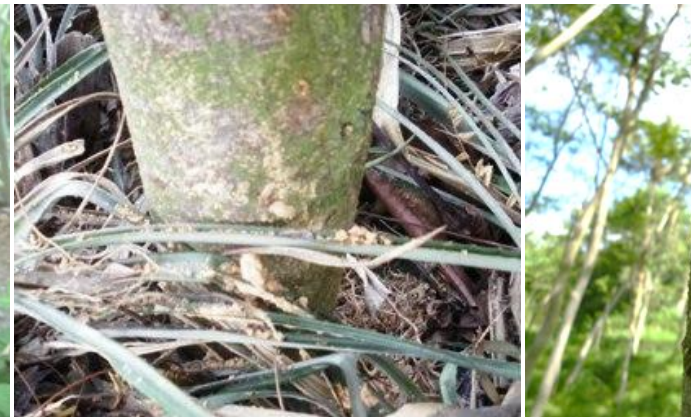

B

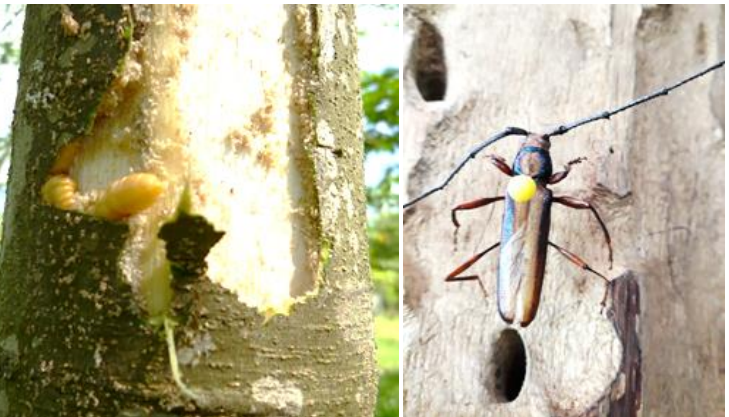

C
D

Figure 2. A. The initial hole of stem borer on one-year-old trees, B. Fresh sawdust indicating new larva borer inside the wood bark of three-year-old trees, C. Advanced stem damage, D. Adult of stem borer Xystrocera festiva, on four-year-old trees (after released from pineapple shrubs) in the agroforestry system. 


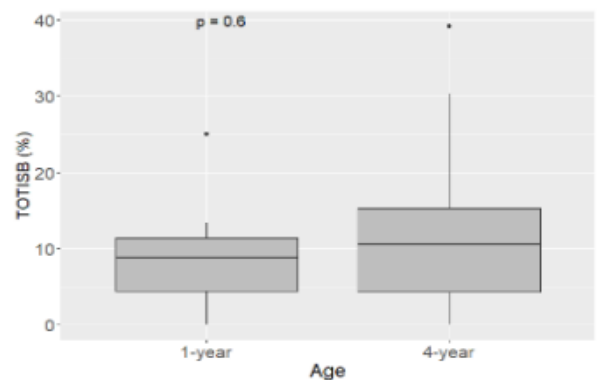

$\mathbf{A}$

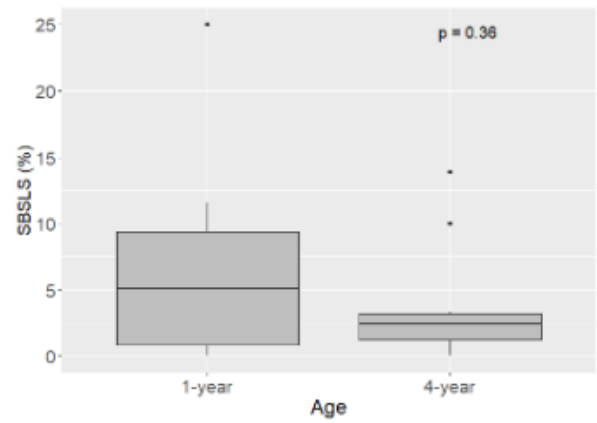

C

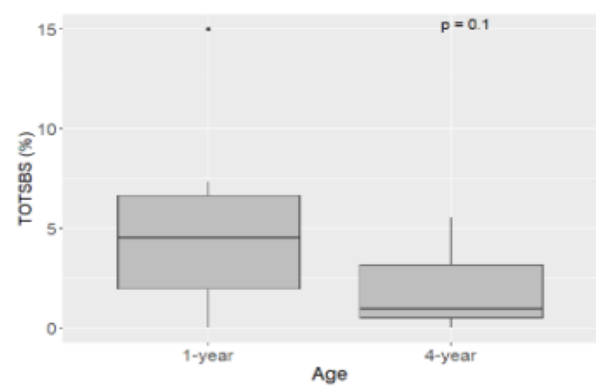

B

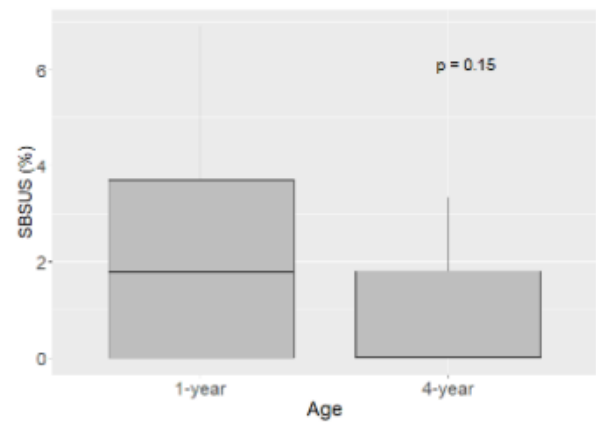

D

Figure 3. The average total stem borer: A. incidence (TOTISB), B. severity (TOTSBS), C. severity on the lower stem (SBSLS), D. severity on the upper stem (SBSUS) on one-year and four-year-old trees

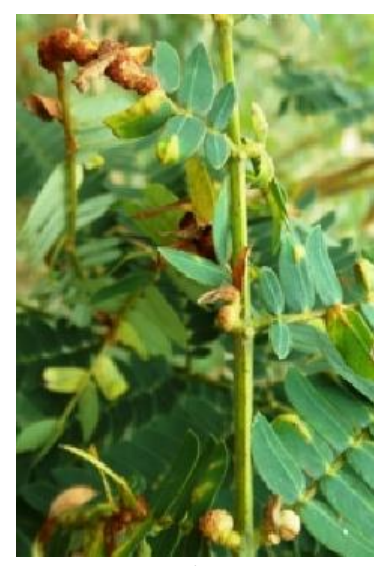

A

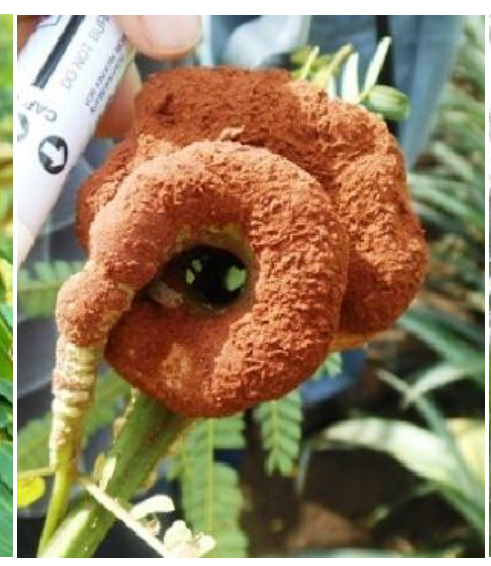

B

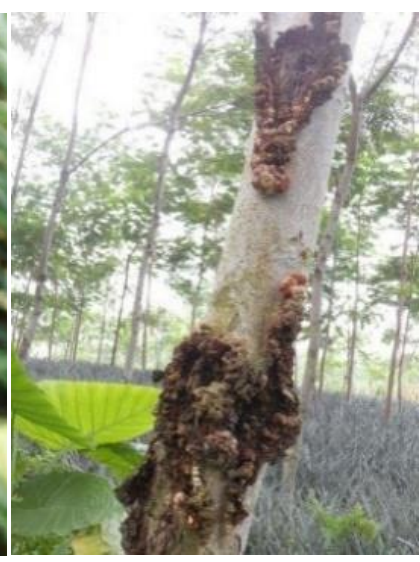

C

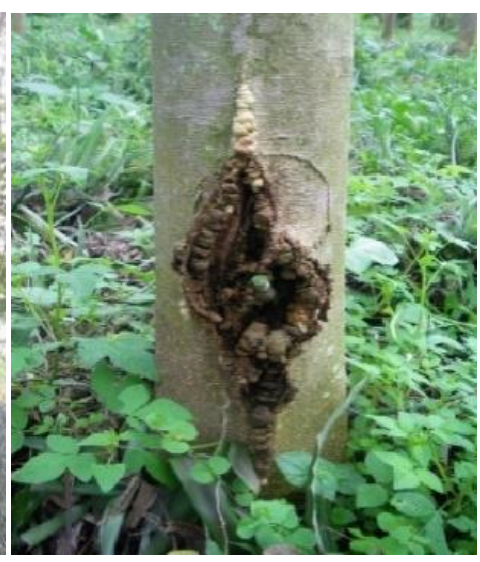

D

Figure 4. The gall rust symptoms on trees of Falcataria moluccana in the Sengon-pineapple agroforestry system: A. On the leaf and B. Swollen branches covered with reddish-brown teliospores on three-month-old trees, C. Galls on the stem of one-year-old trees, D. Galls on the stem of four-years-old trees after the system were freed from pineapple

Another disease on Sengon is caused by the mistletoe belonging to the genus Scurrula. The mistletoe infested the trees right from the age of one yr. However, the infestation often goes undetected, due to its small size, color similarity with the leaves of Sengon, and occurrence on areas not easily visible unless closely examined (Figure 7). Since the mistletoe is an obligate parasite, it can live on the host during its entire lifecycle. Initially, the number of trees with mistletoe and its number on each tree was less than $1 \%$ on one-year-old trees. However, due to its continuous development and infestation, the incidence and the intensity increased to $12 \%$ and $17 \%$, respectively in fouryear-old trees (Figure 8). 


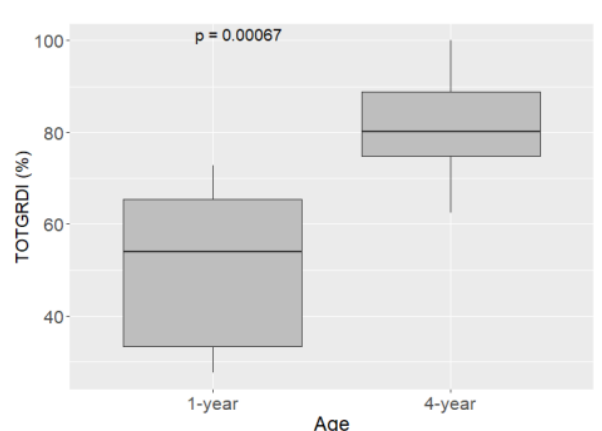

A

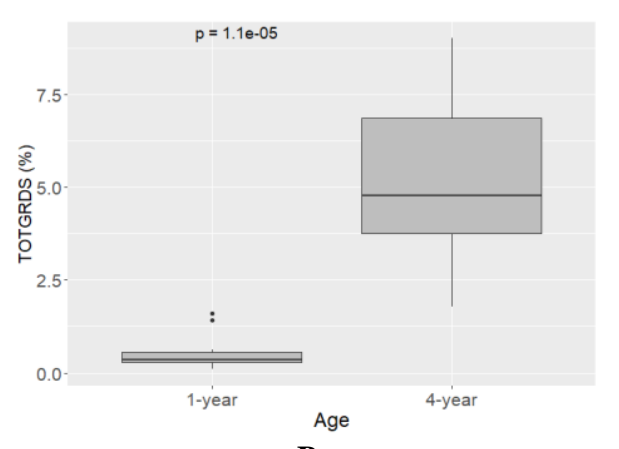

B

Figure 5. A. The average gall rust disease incidence (TOTGRDI), B. Rust disease severity (TOTGRDS) on one- and fouryear-old Falcataria moluccana trees in the agroforestry system with pineapple

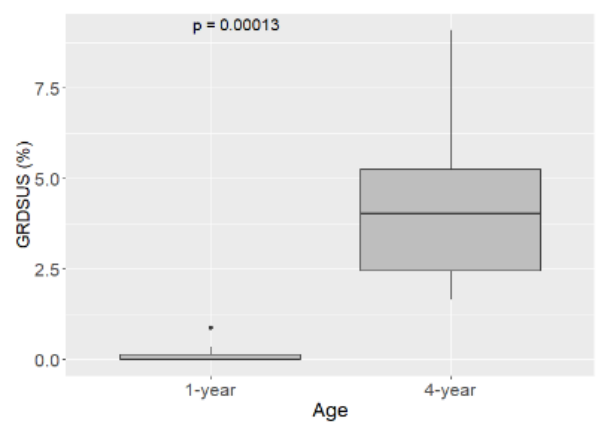

A

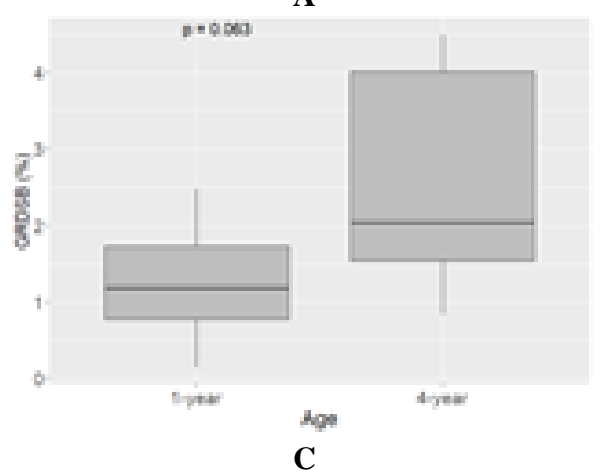

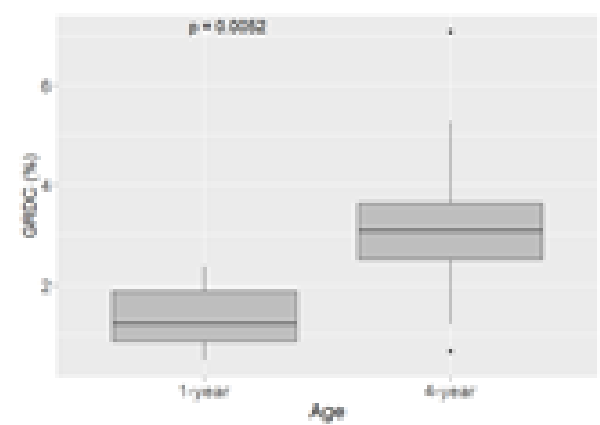

B

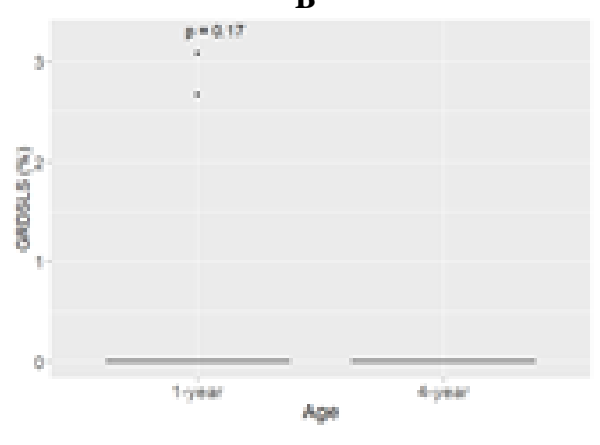

D

Figure 6. The average gall rust disease severity on the: A. Upper stem (GRDSUS), B. Branch (GRDSB), C. Canopy (GRDC), D. Lower stem (GRDSLS) on one- and four-years-old Falcataria moluccana trees growing in the agroforestry system with pineapple.

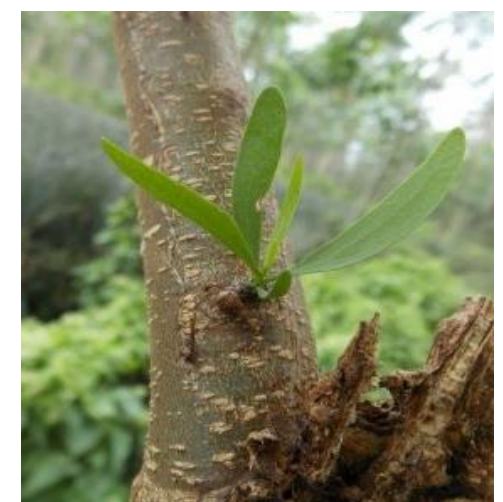

A

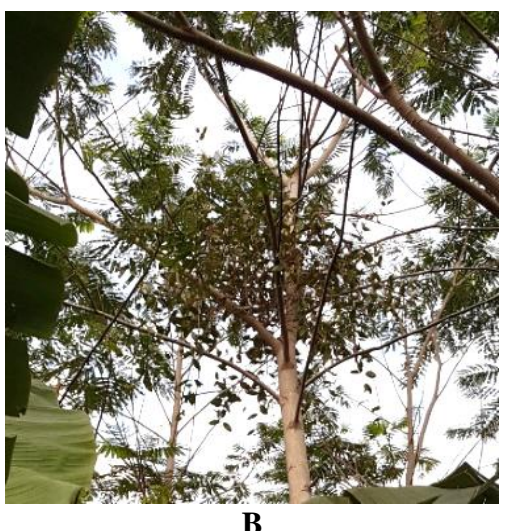

B

Figure.7. A. A tiny mistletoe on the stem of one-year-old Sengon trees, B. Mistletoe from genus Scurulla on the stem and branches of four-year-old trees, growing in the agroforestry system with pineapple 


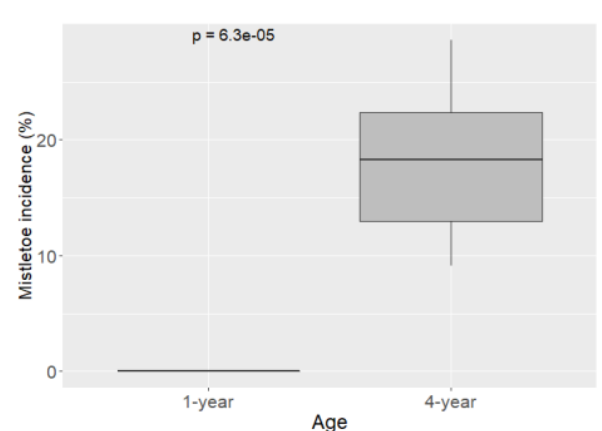

$\mathbf{A}$

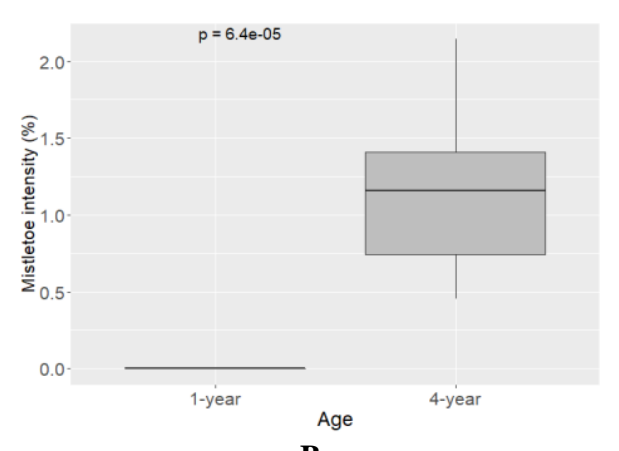

B

Figure 8. Mistletoe: A. Incidence and B. Intensity on one-year and four-year-old Sengon trees growing in the agroforestry system with pineapple.

All the diseases and pests discussed above affected the growth and caused mortality of Sengon trees though at different levels. Based on the stepwise correlation analysis, the factors negatively correlated with the stem diameter of one-year-old trees were stem borer severity on the upper stem (SBSUS), total stem borer severity (TOTSBS), gall rust disease severity on the upper stem (GRDUS), gall rust disease severity on the trunk (GRDST) and the incidence of gall rust disease (GRDI) (Equation 1). However, on fouryear-old trees, none of the disease-causing factors was negatively correlated with the stem diameter (Equation 2). Factors that positively correlated with the percentage mortality of one-year-old trees were the gall rust disease severity on the lower stem (GRDSLS) and the gall rust disease severity on the branch (GRDSB) (Equation 3). While on four-year-old trees, only infestation by mistletoe caused tree mortality (Equation 4). High mortality rates for four-year-old trees were recorded since the gall rust disease and stem borer infestation persisted throughout the life of the trees affecting growth (Figure 9).

Diameter of one-year-old trees $(\mathrm{cm})=8.6+(8.12 *$ SBSLS $)+$ $(-012 *$ SBSUS $)+(-0.42 *$ TOTSBS $)+(-3.32 *$ GRDSUS $)+$ $(0.41 *$ GRDST $)+(0.05 *$ GRDI $)$

Diameter of four$(0.197 *$ GRDST).
Mortality of one-year-old trees $(\%)=-112.8+(10.096 *$ SBSUS $)+$ $(3.41 *$ TOTSBS $)+(-17.03 *$ GRDSLS $)+(146.86 *$ GRDSUS $)+$ $(-36.12 *$ GRDSB $)+(4.7 *$ GRDST $)+(2.2 *$ TOTGRDI $)$ ..(3)

Mortality of four-year-old trees $(\%)=29.436+(5.247 * \mathrm{MS})$

\section{Discussion}

An agroforestry system that involves a tree crop shall show a reduction or no effect on pest and diseases load depending on the host plant, the pest species as well as the management regimes (Armengot et al. 2019). In general, pest abundance and plant damage are reported to be lower in agroforestry treatments for perennial, but not for annual crops. According to Bisseleua (2013), it is possible that the constant shading by trees on perennial crops reduces the number of pests. This was true for the agroforestry system with pineapple plants which had no significant pests or diseases affecting them. However, Sengon trees were affected by several pests and diseases which were more diverse than in a monoculture system. According to Chung and Paul (2018), attack by Xystrocera festiva and the gall rust disease was the only pest and disease problems in the monoculture of F. moluccana in Sabah, Malaysia. This was also true for Sengon monoculture in Indonesia (Nair and Sumardi, 2001).

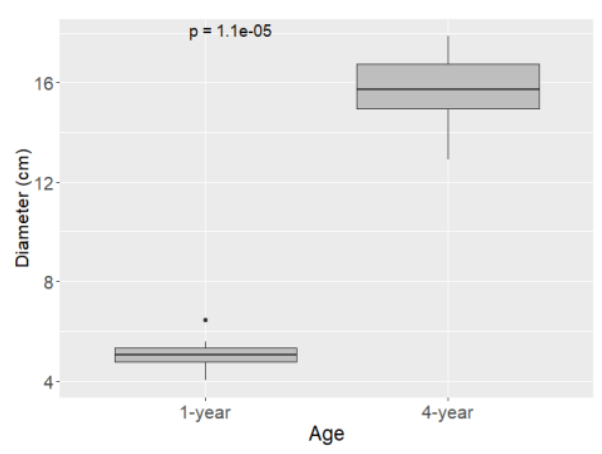

A

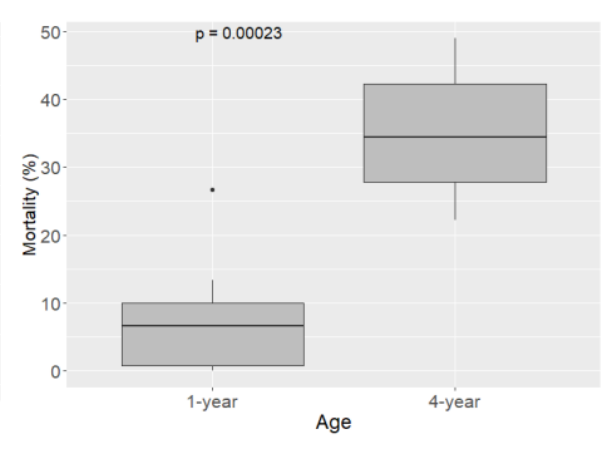

B

Figure 9. A. Diameter and B. Percent mortality of one-year and four-year-old trees growing in the agroforestry system. 
However, in the present study, the occurrence of white grub and mistletoe was recorded as additional problems in the Sengon-pineapple agroforestry system. Based on discussions with the field staff and observations in the agroforestry system, it was noted that application of compost, contaminated with white grub eggs, in the pineapple planting was the reason for the occurrence of white grub disease on Sengon trees. Moreover, application of liquid waste from sugarcane distillation units in order to make the pineapple fruits juicier, also contributed to the proliferation of white grubs in the agroforestry system. Incidence of white grub issues in sugarcane crops has been reported from several countries including Indonesia and India (Kalshoven et al. 1981; Bhattacharyya et al. 2015).

Sengon trees either in monoculture, mixed plantations or in an agroforestry system, are not free from attack by the stem borer Xystrocera festiva. According to Endang and Farikhah (2010), infestation of $X$. festiva begins when the female beetle lays eggs in the crevices of bark or in wounds on the stem or branch of the tree. The newly hatched larvae feed gregariously on the inner part of the bark and the outer part of sapwood, forming small feeding tunnels as deep as $0.5 \mathrm{~cm}$. The tunnels run downwards from the site of the egg cluster towards the lower part of the stem of Sengon trees. The feeding tunnels become wider when the larvae become bigger. The larvae push out frass and a brown liquid through the tunnels which lie on the forest floor as evidence of pest attack. The incidence of stem borer attack on one and four-year-old trees in the agroforestry system was about $10 \%$ and $11 \%$ respectively, which were lower than the stem borer incidence in the monoculture of fouryear-old Sengon plantations (Endang and Farikhah (2010). This difference in incidence can also be related to the reduced density of the Sengon trees in the agroforestry system. Results of this study have shown that infestation by $X$. festiva in one and four-year-old trees were more severe at the lower stem than the upper stem. It is probable that the favorable microclimatic conditions close to the ground in the Sengon-pineapple agroforestry system helps the borer to lay egg and develop larvae on the lower stem of Sengon trees, especially when the trees still young at one-year-old.

The notable difference here is that though the gall rust disease was widespread in both one-year and four-year-old Sengon trees in the agroforestry system, the severity of the disease was exceptionally low compared to that in monocultures. Rahayu et al. (2018) reported that the gall rust disease was widespread and severe in a four-year-old Sengon monoculture in Tawau-Sabah, Indonesia. The low severity of gall rust disease in the Sengon-pineapple agroforestry may be attributed to the wider spacing of Sengon trees under the system $\left(3 \times 4 \mathrm{~m}^{2}\right)$ compared to the general monoculture system $\left(2 \times 3 \mathrm{~m}^{2}\right)$. The wider spacing provided a more open canopy of trees reducing the humidity within the system which is unsuitable for formation of teliospore of the fungus to cause infection. And, an increased wind speed may have controlled disease spread within the agroforestry system. Pineapple, an herbaceous perennial, with a short $(0.5 \mathrm{~m}$ to $1 \mathrm{~m})$ and stocky stem with tough and waxy leaves may have also contributed to lowering humidity at the site. Although the severity of rust disease was very low in the intercropped system, the incidence of the disease was almost similar to that in a monoculture system. This may be due to the development of fog in the agroforestry system which is located at high altitudes (424 $\mathrm{m}$ asl.) (Rahayu et al. 2018, 2019). To summarize, although the general environmental conditions in the Sengon-pineapple agroforestry system are not very conducive for gall rust severity, the presence of fog may promote incidence and spread of the disease at the site.

Infestation of Sengon trees by mistletoe either in monoculture or agroforestry system is rarely reported. According to Hodar et al. (2018), mistletoes draw water and mineral resources from host plants, attaining higher concentrations of foliar nutrients than their hosts. In young trees, mistletoe seed production can be vigorous and result in extensive infection and spread of the parasite, but subsequent impacts depend on density and growth of the young stands. Furthermore, where the stands remain relatively open, mistletoe infection can keep pace with the height growth of the tree, and the trees get severely infected (Arruda et al. 2012). The results of the present study show that the incidence and severity of mistletoe increased from one year to four-year-old trees. However, even a low incidence of mistletoe infestation in young Sengon trees can affect tree health significantly especially after thinning or partial cutting. According to Muir et al. (2004), individual mistletoe infection on stem or lower branches of living trees can retain its quiescent state for several years and then resume vigorous seed production in response to disturbance to the tree. However, Matula et al. (2015), mentioned that distribution of mistletoe entirely depends on the habit of the birds that disseminate the mistletoe seed. The agroforestry system with Sengon may be a suitable habitat for birds similar to the teak-crop-based agro-ecosystem reported by Imron et al. (2018). Planting fruit trees in the vicinity of the plantation may provide an alternate habitat for birds and distract them from disseminating mistletoe seed on Sengon trees and save the trees from mistletoe infestation.

The findings of this study showed that the pest and disease problems in the Sengon-pineapple agroforestry system present a complex interaction of several factors different from that in a monoculture. The ecological hypothesis on the incidence of pests and diseases in different crops in agroforestry systems is focused more on the changes in the micro-climate within the system. According to Bright et al (2017), the microclimate hypothesis is based on the observation that agroforestry practices affect the microclimate around the crop through shading of the understory crops, higher relative humidity, lower air and soil temperatures, and decreased wind speed. However, all these depend on the crops chosen for developing an agroforestry system and the spacing between and among different crops. The changes in microclimate may have negative, positive, or neutral impacts on weeds, pathogens, insect, and their natural enemies (Altieri et al. 2017). The agroforestry system including Sengon and pineapple presents a different scenario compared to a 
normal agroforestry system discussed by Bright et al. (2017). As discussed, the wider spacing between the trees resulted in lower relative humidity, higher exposure to sunlight and higher wind speed in the system. In addition, the stiff and waxy leaves of pineapple also contributed to lowering the relative humidity around the trees. The resultant changes in microclimatic conditions are less conducive for increasing the severity of the gall rust disease and stem borer attack.

In conclusion, the agroforestry system involving Falcataria moluccana (Sengon) and pineapple reduced the severity of gall rust disease caused by Uromycladium falcatarium and stem borer attack by Xystrocera festiva in Sengon trees apparently influenced by a change in the micro-climate in the ecosystem. The pineapple was unaffected by any disease. However, the intercropping brought in a new pest, the white grub which affected the early growth of the Sengon trees. The white grub incidence was noted to be through fertilizers applied to pineapple which were contaminated with eggs of white grubs. The mistletoe infestation in Sengon trees cannot be related to any influence of the intercropping but a chance occurrence. Early detection and intensive monitoring are necessary to eliminate the infestation of mistletoe which caused high mortality of Sengon trees. Overall, while the agroforestry system of Sengon and pineapple resulted in some benefits with regard to the severity of gall rust disease and stem borer attack, it brought in the white grub problem which calls for applying contaminant-free fertilizers in pineapple planting.

\section{ACKNOWLEDGEMENTS}

This research was funded by the Public Fun Fiscal Year 2020 of Faculty of Forestry, Universitas Gadjah Mada, Yogyakarta, Indonesia under contract No. 119/KS/2020. Technician and bachelor student as enumerator for their contribution on data collected.

\section{REFERENCES}

Allsopp PG. 2010. Integrated management of sugarcane white grubs in Australia: an evolving success. Annu Rev Entomol 55: 329-349

Altieri MA, Nicholls CI, Henao A, Marcos AL. 2017. Agroecology and the design of climate change-resilient farming systems. Agron. Sustain. Dev. 35:869-890 DOI: 10.1007/s13593-015-0285-2

Arakaki N, Hokama Y, Nagayama A, Yasui H, Fujiwara-Tsujii N, Tanaka S, Mochizuki F, Naito T, Hongo T, Wakamura S. 2013. Mating disruption for control of the white grub beetle Dasylepida ishigakiensis (Coleoptera: Scarabaeidae) with synthetic sex pheromone in sugarcane fields. Appl Entomol Zool 48: 441-446. DOI: $10.1007 / \mathrm{s} 13355-013-0202-6$

Armengot L, Ferrari L, Milz J, Velásquez F, Hohmann, P, Schneider M 2019. Cacao 291 agroforestry systems do not increase pest and disease incidence compared with 292 monocultures under good cultural management practices. Crop Prot 105047. 293 DOI: 10.1016/j.cropro.2019.105047

Arruda R, Fadini RF, Carvalho LN, Del-Claro K, Mourão FA, Jacobi CM, Grazielle ST, Eduardo VB, Claudenir SC, Greta AD. 2012. Ecology of neotropical mistletoes: an important canopy-dwelling component of Brazilian ecosystems. Acta Botanica Brasilica. 26 (2): 264-74.

Bhattacharyya B, Pujari D, Bhuyan U, Handique G, Baruah AALH, Dutta SK, and Tanaka S. 2015. Seasonal life cycle and biology of Lepidiota mansueta (Coleoptera: Scarabaeidae): a serious root-feeding pest in India. Appl Entomol Zool DOI: 10.1007/s13355-015-0349-4

Bisseleua HBD, Fotio D, Missoup AD, Vidal S. 2013. Shade tree diversity, cocoa pest damage, yield compensating inputs and farmers' net returns in West Africa. PloS one 8 (3): e56115.

Bright RM, Davin E, Halloran TO, Pongratz J, Zhao K, and Cescatti, A. 2017. Local temperature response to land cover and management change driven by non-radiative processes. Nat Clim Chang 7: 296302.

Chung AYC, Paul V. 2018. An overview of forest insect pest and disease research in sustainable forest management in Sabah. In: Liaw HL, William WW, Wong EM (eds). Proceedings of The Seminar on Managing Pests and Diseases for Sustainable Agriculture. Society of Agricultural Scientists Sabah \& Department of Agriculture, Sabah, Malaysia. 16-17 August 2016.

Endang AH, Farikhah HN. 2010. Infestation of Xystrocera Festiva In Paraserianthes Falcataria Plantation In East Java, Indonesia. J Trop For Sci 22 (4): 397-402

Gliessman SR. 2015. Agroecology the ecology of sustainable food systems. 3rd edition. Taylor \& Francis Group

Hódar JA, González AL, Zamora R. 2018. Beneath the mistletoe: parasitized trees host a more diverse herbaceous vegetation and are more visited by rabbits. Ann For Sci 75: 77 DOI: 10.1007/s13595018-0761-3

Imron MA, Tantaryzard M, Satria RA, Maulana I \& Pudyatmoko S. 2018. Understory avian community in a teak forest of cepu, central java. J Trop For Sci 30 (4): 509-518. DOI: $10.26525 / \mathrm{jtfs} 2018.30 .4 .509518$

Kalshoven LGE, Laan PA van der, 1981. Pests of crops in Indonesia. Ichtiar Baru. Jakarta, Indonesia.

Karmini, Sarminah S, Karyati. 2017. Economic analysis of groundnut (Arachis hypogaea) and soybean (Glycine max) as intercropping plants in two agroforestry systems. Biodiversitas 18 (2): 483-493. DOI: 10.13057/biodiv/d180206

Kosuke M, Mugniesyah SS, Herianto AS et al. 2013. Talun-Huma, Swidden Agriculture, and Rural Economy in West Java, Indonesia. Southeast Asian Studies 2 (2): 351-381.

Krisnawati H, Varis E, Kallio M, and Kanninen M. 2011 Paraserianthes falcataria (L.) Nielsen: ecology, silviculture and productivity. Center for International Forestry Research (CIFOR), Bogor, Indonesia. DOI: $10.17528 /$ cifor/003394

Matula R，Svátek M，Pálková M，Volař́ik D，Vrška T. 2015. Mistletoe Infection in an Oak Forest Is Influenced by Competition and Host Size. PLOS ONE 10 (5): e0127055. DOI: 10.1371/journal.pone.0127055.

Muir JA, Robinson DCE, Geils BW. 2004. Characterizing the effects of dwarf mistletoe and other diseases for sustainable forest management. BC J Ecosyst Manag 3 (2): 1-7.

Nair KSS and Sumardi. 2000. Insects Pest and Diseases of Major Plantation Species. In: Nair KSS (ed). Insect Pest and Disease in Indonesian Forest: an Assessment of The major Treats, Research Efforts and Literature. Center for International Forestry Research (CIFOR), Bogor. Indonesia. DOI: 10.17528/cifor/000700

Palma RA, Tiongco OPL, Canencia E, Boniao R.D, Florida EJ, Dagonio JY. 2020. Gall rust disease incidence of Falcata (Paraserianthes falcataria (L.) Nielsen) in Falcata - based agroforestry systems in Misamis Oriental, Philippines. IOP Conf. Series: Earth and Environmental Science 449 (2020): 012035. DOI:10.1088/17553315/449/1/012035

Rahayu S, Lee SS, Shukor NAA, Saleh G. 2018. Environmental Factors Related to Gall Rust Disease Development on Falcataria moluccana (Miq.) Barneby \& J.W. Grimes at Brumas Estate, Tawau, Sabah, Malaysia. Journal of Ecology and Environmental Research. 16 (6): 7485-7499. DOI:10.15666/aeer/1606_74857499

Rahayu S, Widiyatno and Adriyanti DT. 2020. Pathogenesis of Gall-Rust Disease on Falcataria moluccana in Areas Affected by Mount Merapi Eruption in Indonesia. Biodiversitas 21 (4): 1310-1315. DOI: $10.13057 /$ biodiv/d210406

Saikia P, Kumar A, Khan ML. 2017. Agroforestry: A Sustainable Land use System for Livelihood Security and Climate Change Mitigation. In: Pandey CB, Gaur MK, Goyal RK (Eds) Climate Change and Agroforestry. New India Publishing Agency, New Delhi, India

Schroth G, Krauss U, Gasparotto LJAD. Aguilar A, K Vohland. 2000. Pests and diseases in agroforestry systems of the humid tropics. Agroforestry Systems 50: 199-241. DOI: 10.1023/A:1006468103914 
Sharma SP, Doyle V, Shandil dan S Talakia'atu. 2010. Towards understanding models for statistical literacy: a literature review. Waikato Journal of Education 15 (3): 116-128.

Weifeng1 Z, Weixiu Y, Zhiling M, Zhang X, Cha L, Liu S, and Zhang Y. 2020. Effects of time and height of shading on yield and quality of pineapple. IOP Conf Ser: Earth Environ Sci 512: 012101.
Wijayanto N. 2011. Species identification and selection to develop agroforestry at Lake Toba Catchment Area (LTCA). Biodiversitas 12 (1): 52-58. DOI: 10.13057/biodiv/d120110 